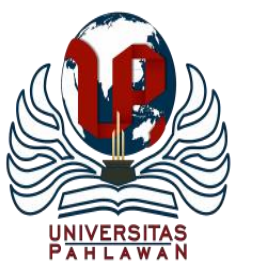

Jurnal Basicedu Volume 4 Nomor 2 April 2020 Hal. 443 - 452

JURNAL BASICEDU

Research \& Learning in Elementary Education

https://jbasic.org/index.php/basicedu

\title{
ANALISIS SUPERVISI KEPALA SEKOLAH DALAM PENYUSUNAN RPP DAN PELAKSANAAN MODEL SAINTIFIC DI SEKOLAH DASAR
}

\author{
Wisma Diandra ${ }^{1}$, Sufyarma Marsidin ${ }^{2}$, Ahmad Sabandi $^{3}$ Ahmad Zikri $^{4}$ \\ Universitas Negeri Padang, Sumatera Barat, Indonesia ${ }^{1,2,3,4}$ \\ e-mail : : wismadiandra@gmail.com ${ }^{1}$, sufyarma1954@gmail.com ${ }^{2}$, sabandi@fip.unp.ac.id ${ }^{3}$, zikria79@yahoo.com ${ }^{4}$
}

\begin{abstract}
Abstrak
Tujuan penelitian ini untuk menganalisis supervisi kepala sekolah dalam penyusunan RPP dan pelaksanaan model saintifik di Sekolah Dasar. Jenis penelitian adalah penelitian deskriptif kualitatif. Populasinya adalah guru-guru di Gugus V kecamatan Latina Kota Payakumbuh. Pengambilan sampel dilakukan dengan purpose sampling. Data penelitian dikumpulkan melalui kegiatan supervisi yang dilakukan di Gugus V Kecamatan Latina. Berdasarkan Hasil penelitian yang diperoleh menunjukkan bahwa kegiatan supervisi yang dilakukan kepala sekolah berjalan dengan baik. Dapat disimpulkan bahwa analisis kegiatan supervisi kepala sekolah di gugus V kecamatan Latina menunjukan pemahaman guru SD di Kecamatan Latina tentang RPP cukup bervariasi, pada intinya mereka cukup baik dalam memahami tentang media, walaupun ada diantara mereka RPP dalam artian yang terlalu umum.
\end{abstract}

Kata Kunci : Supervisi, Model Saintifik, Sekolah Dasar.

\begin{abstract}
The purpose of this study is to analyze the principal's supervision in the preparation of lesson plans and the implementation of scientific models in elementary schools. This type of research is a qualitative descriptive study. The population is the teachers in Group V of the Latina Payakumbuh district. Sampling is done with the aim of sampling. Research data was collected through surveillance activities carried out in Group V of the Latina District. Based on the results of the study showed that the principal's supervision activities went well. It can be concluded that the analysis of principals' supervision activities in Latina $\mathrm{V}$ district shows that primary school teachers in Latina District are quite diverse, basically they are quite good at understanding the media, although some of them are RPP in a very general sense.

Keywords : Supervision, Scientific Model, Elementary School
\end{abstract}

@ Jurnal Basicedu 2020

$\triangle$ Corresponding author :

Address : Air Tawar Padang

Email : wismadiandra@gmail.com

ISSN 2580-3735 (Media Cetak)

Phone : 089531307164

ISSN 2580-1147 (Media Online) 
444 Analisis supervisi kepala sekolah dalam penyusunan RPP dan pelaksanaan model saintific di sekolah dasar - Wisma Diandra, Sufyarma Marsidin, Ahmad Sabandi, Ahmad Zikri

\section{PENDAHULUAN}

Perkembangan informasi dan teknologidi era tanpa batas ini menuntut sumber daya manusia yang berkualitas. Salah satu faktor penting dalam peningkatan sumber daya manusia adalah pendidikan. Pendidikan menjadi fondasi dari perkembangan suatu bangsa dan hal ini menuntut pendidikan untuk terus memperbarui sistemnya. Fenomena ini juga berpengaruh pada proses pendidikan di Indonesia yang masih terus dikembangkan. Salah satu usaha pemerintah dalam memperbaiki dan mengembangkan mutu pendidikan di Indonesia adalah penyempurnaan kurikulum(Piaget, 2010).

Kurikulum merupakan salah satu sarana dalam mewujudkan tujuan pendidikan nasional. Kurikulum disusun secara nasional di Indonesia, dengan tujuan agar setiap warga negara, dimanapun ia bersekolah, mempunyai kesempatan memperoleh kompetensi yang sama (Asmendri, Marsidin, Rusdinal, \& Mukhaiyar, 2018). Sistem Pendidikan Nasional (SPN) di Indonesia telah mengalami sepuluh kali perubahan kurikulum, dalam rangka menghadapi berbagai tantangan yang timbul seiring dengan perkembangan zaman, ilmu pengetahuan dan teknologi, tingkat kecerdasan peserta didik, kultur, sistem nilai, dan kebutuhan masyarakat (Mislinawati. \& Nurmasyitah., 2018). Menghadapi berbagai tantangan yang timbul, baik yang bersifat internal maupun eksternal, pemerintah menilai perlumelakukan pengembangan terhadap kurikulum tingkat satuan pendidikan menjadi kurikulum baru yang berbasis karakter dan berbasis kompetensi yang dapat membekali peserta didik dengan sikap dan kemampuan yang sesuai dengan tuntutan perkembangan zaman dan teknologi (E. Mulyasa, 2013).

Pengembangan kurikulum yang dilakukan pemerintah menghasilkan kurikulum baru yang dinamakan kurikulum 2013 atau K-13. Orientasi
Kurikulum 2013 adalah terjadinya peningkatan dan keseimbangan antara kompetensi sikap (attitude), keterampilan (skill) dan pengetahuan (knowledge) (Utami, Yamtinah, \& ES, 2016). Hal ini sejalan dengan amanat Undang-Undang Nomor 20 Tahun 2003 tentang Sistem Pendidikan Nasional sebagaimana tersurat dalam Penjelasan Pasal 35 yang menyatakan, bahwa kompetensi lulusan merupakan kualifikasi kemampuan lulusan yang mencakup sikap, pengetahuan, dan keterampilan sesuai dengan standar nasional yang telah disepakati (Depdiknas, 2003).

Permendikbud No. 67 tahun 2013 tentang Kurikulum SD, didalamnya berisi kurikulum 2013 dirancang dengan karakteristik sebagai berikut: (a) mengembangkan keseimbangan antara pengembangan sikap spiritual dan sosial, rasa ingin tahu, kreativitas, kerja sama dengan kemampuan intelektual dan psikomotorik; (b) sekolah merupakan bagian dari masyarakat yang memberikan pengalaman belajar terencana dimana peserta didik menerapkan apa yang dipelajari di sekolah ke masyarakat dan memanfaatkan masyarakat sebagai sumber belajar; (c) mengembangkan sikap, pengetahuan, dan keterampilan serta menerapkannya dalam berbagai situasi di sekolah dan masyarakat; (d) memberi waktu yang cukup leluasa untuk mengembangkan berbagai sikap, pengetahuan, dan keterampilan; (e) kompetensi dinyatakan dalam bentuk kompetensi inti kelas yang dirinci lebih lanjut dalam kompetensi dasar mata pelajaran; (f) kompetensi inti kelas menjadi unsur pengorganisasi (organizing elements) kompetensi dasar, dimana semua kompetensi dasar dan proses pembelajaran dikembangkan untuk mencapai kompetensi yang dinyatakan dalam kompetensi inti; (g) kompetensi dasar dikembangkan didasarkan pada prinsip akumulatif, saling memperkuat (reinforced) dan memperkaya (enriched) antar matapelajaran dan jenjang pendidikan (organisasi horizontal dan 
445 Analisis supervisi kepala sekolah dalam penyusunan RPP dan pelaksanaan model saintific di sekolah dasar - Wisma Diandra, Sufyarma Marsidin, Ahmad Sabandi, Ahmad Zikri

vertikal) (Sufairoh, 2016). Dengan demikian tujuan Kurikulum 2013 adalah untuk mempersiapkan manusia Indonesia agar memiliki kemampuan hidup sebagai pribadi dan warga negara yang beriman, produktif, kreatif, inovatif, dan afektif serta mampu berkontribusi pada kehidupan bermasyarakat, berbangsa, bernegara, dan peradaban dunia. Keberhasilan kurikulum diartikan sebagai pencapaian kompetensi yang dirancang dalam dokumen kurikulum oleh seluruh peserta didik dalam bentuk pembelajaran tematik.

Kurikulum 2013 dan Kurikulum Tingkat Satuan Pendidikan (KTSP) memiliki perbedaan dalam sistem pembelajaran. Kurikulum Tingkat Satuan Pendidikan pembelajarannya dilaksanakan masih terpisah-pisah, siswa aktif serta lebih menekankan hasil daripada proses pembelajaran. Sedangkan kurikulum 2013 dilaksanakan secara tematik integratif dengan menggunakan pendekatan saintifik dan penilaian otentik. Dalam kegiatan belajar dengan pendekatan saintifik, guru mengajak siswa mengamati, menanya, mengumpulkan informasi / eksperimen, mengasosiasi/mengolah informasi, dan mengomunikasikan materi yang dipelajari. Adapun penilaian autentik, guru menilai proses dan hasil belajar siswa (Dahliana, 2014; Kusno, 2014; Salihin, 2014). Perbedaan esensial antara Kurikulum Tingkat Satuan Pendidikan (KTSP) dan Kurikulum 2013 untuk Sekolah Dasar/Madrasah Ibtidaiyah adalah dalam pembelajaran tematik. Dalam Kurikulum Tingkat Satuan Pendidikan (KTSP), mata pelajaran tertentu mendukung kompetensi tertentu dan mata pelajaran dirancang berdiri sendiri dan memiliki kompetensi dasar sendiri (Baridan, 2016; Depdiknas, 2006; Muslich, 2008).

Setiap mata pelajaran diajarkan dengan pendekatan berbeda, dan setiap jenis konten pembelajaran diajarkan terpisah. Sedangkan pembelajaran tematik dalam K13 setiap mata pelajaran mendukung semua kompetensi (sikap, keterampilan, dan pengetahuan). Mata pelajaran dirancang terkait dengan yang lain dan memiliki kompetensi dasar yang diikat oleh kompetensi inti tiap kelas. Semua mata pelajaran diajarkan dengan pendekatan yang sama (saintifik) melalui mengamati, menanya, mencoba, dan menalar. Bermacam jenis konten pembelajaran diajarkan terikat dan terpadu satu sama lain (Tarmili, 2016).

Berdasarkan observasi yang dilakukan, kota Payakumbuh sudah melaksanakan kurikulum 2013 sejak tahun 2014 tahun pelajaran 2018/2019. Data yang didapat dari dinas pendidikan kota Payakumbuh berdasarkan pelaksanaan kurikulum 2013 di beberapa kecamatan di Payakumbuh, dikatakan bahwa: 1) Kecamatan Payakumbuh Utara dan Latina,terdapat 15 sekolah dimana seluruh kelas telah menerapkan kurikulum 2013. Dari 36 Sekolah Dasar, 21 nya baru memasuki tahun ke dua pelaksanaan kurikulum 2013. 2) Kecamatan Payakumbuh Barat, terdapat 21 Sekolah yang sudah menerapkan kurikulum 2013 diseluruh kelas dimana dari 38 Sekolah Dasar, 17 nya baru memasuki tahun ke dua pelaksanaan kurikulum 2013. 3) Kecamatan Payakumbuh Timur, terdapat 15 Sekolah yang sudah menerapkan kurikulum 2013 diseluruh kelas. Dari 22 Sekolah Dasar, 7 nya baru memasuki tahun ke dua pelaksanaan kurikulum 2.

Mengatasi masalah tersebut, maka diperlukan untuk analisis mendalam bagaimana pemahaman guru Sekolah Dasar dalam menyusun RPP dan menerapkan model pembelajaran pada Kurikulum 2013 sehingga pembelajaran dapat terlaksana dengan baik sesuai dengan satuan pendidikan dan peserta didik dapat mencapai kompetensi yang dicanangkan. Maka penelitian ini akan mengalisis Rencana Pelaksanaan Pembelajaran (RPP) dan menerapkan model pembelajaran pada Kurikulum 2013 oleh Guru 
Sekolah Dasar di kecamatan Latina kota Payakumbuh.

\section{METODE PENELITIAN}

Penelitian ini menggunakan metode penelitian deskriptif kualitatif. Penelitian kualitatif dilakukan karena peneliti ingin mengeksplor fenomena-fenomena yang tidak dapat dikuantifikasikan yang bersifat deskriptif seperti proses suatu langkah kerja, formula suatu resep, pengertian-pengertian tentang suatu konsep yang beragam, karakteristik suatu barang dan jasa, gambargambar, gaya-gaya, tata cara suatu budaya, model fisik suatu artifak dan lain sebagainya (Creswell, 2016).

Berdasarkan keterangan tersebut, dapat ditarik kesimpulan bahwa penelitian deskriptif kualitatif yaitu rangkaian kegiatan untuk memperoleh data yang bersifat apa adanya tanpa ada dalam kondisi tertentu yang hasilnya lebih menekankan makna. Peneliti menggunakan metode penelitian deskriptif kualitatif karena penelitian ini menganalisis secara mendalam mengalisis Rencana Pelaksanaan Pembelajaran (RPP) berdasarkan model pembelajaran pada Kurikulum 2013 oleh Guru Sekolah Dasar di kecamatan Latina kota Payakumbuh.

\section{HASIL PENELITIAN DAN PEMBAHASAN}

Berdasarkan data yang diperoleh peneliti melalui wawancara, observasi dan dokmentasi dengan kepala sekolah dan guru pada SD Negeri Latina diperoleh fakta bahwa, kepala sekolah dalam melaksanakan program perencanaan yang baik. Artinya bahwa kepala sekolah sebelum turun ke lapangan terlebih dahulu melalui tahap perencanaan. Misalnya kepala sekolah rutin melaksanakan rapat persiapan, menentukan jadwal supervisi dan perumusan instrumen supervisi

Berdasarkan data yang peneliti peroleh dari narasumber baik dari guru sekolah dasar di kabupaten Latina maupun kepala sekolah, diperoleh data bahwa kepala sekolah pada umumnya mengikuti jadwal yang telah dibuat, namun ada juga kepala sekolah yang tidak mengikuti jadwal.

Adapun yang menjadi sasaran penilaian kepala sekolah adalah perencanaan pembelajaran. Yang menjadi objek penilaian perencanaan pembelajaran guru adalah mulai dari kalender pendidikan, program semester, program tahunan, RPP sampai pada evaluasi yang dilaksanakan oleh guru terhadap peserta didik. Dalam program tahunan atau program semester kepala sekolah menilai guru dalam penyusunan alokasi waktu yang sesuai dengan kalender pendidikan. Kemudian pada penilaian RPP guru, kepala sekolah menilai mulai dari $\mathrm{KD}$, materi, tujuan pembelajaran, metode/teknik pembelajaran dan terakhir pada evaluasinya.

Peningkatan kompetensi tenaga pendidik atau guru di sekolah dasar di kecamatan Latina tidak bisa terlepas dari peran aktif kepala sekolah dalam melaksanakan pembinaan dan pembimbingan kepada guru di sekolah. Karena pembinaan dan pembimbingan kepada guru merupakan tanggung jawab seorang kepala sekolah. Dari hasil wawancara, observasi dan studi dokumentasi dengan narasumber diperoleh fakta bahwa kepala sekolah yang bertugas di sekolah dasar kecamatan Latina aktif dalam membina dan membimbing guru dalam mengembangkan kompetensinya.

\section{Tabel 1. Rekap Hasil Analisis Rpp Guru Gugus} V Kecamatan Latina

\begin{tabular}{|l|l|l|l|l|}
\hline $\begin{array}{l}\text { N } \\
\text { o }\end{array}$ & SD N & $\begin{array}{l}\text { Rata- } \\
\text { Rata } \\
\text { KD }\end{array}$ & $\begin{array}{l}\text { Skor } \\
\text { KD }\end{array}$ & $\begin{array}{l}\text { Predik } \\
\text { et }\end{array}$ \\
\hline 1 & $\begin{array}{l}\text { SD N 08 } \\
\text { Payakumbuh }\end{array}$ & 43,87 & 79,77 & C \\
\hline 2 & $\begin{array}{l}\text { SD N 23 } \\
\text { Payakumbuh }\end{array}$ & 42,5 & 77,39 & C \\
\hline 3 & $\begin{array}{l}\text { SD N 37 } \\
\text { Payakumbuh }\end{array}$ & 43,5 & 79,5 & C \\
\hline 4 & SD N 50 & 44 & 69,09 & C \\
\hline
\end{tabular}


447 Analisis supervisi kepala sekolah dalam penyusunan RPP dan pelaksanaan model saintific di sekolah dasar - Wisma Diandra, Sufyarma Marsidin, Ahmad Sabandi, Ahmad Zikri

\begin{tabular}{|l|l|c|c|l|}
\hline & Payakumbuh & & & \\
\hline 5 & $\begin{array}{l}\text { SD N 62 } \\
\text { Payakumbuh }\end{array}$ & 44,12 & 80,60 & $\mathrm{~B}$ \\
\hline 6 & $\begin{array}{l}\text { SD N 64 } \\
\text { Payakumbuh }\end{array}$ & 43,75 & 79,54 & $\mathrm{C}$ \\
\hline 7 & MIS & 43,25 & 78,63 & $\mathrm{C}$ \\
\hline 8 & MIN & 46,38 & 84,32 & $\mathrm{~B}$ \\
\hline & JUMLAH & 351,37 & 628,84 & \\
\hline & $\begin{array}{l}\text { RATA- } \\
\text { RATA }\end{array}$ & 43,92 & 78,61 & $\mathrm{C}$ \\
\hline
\end{tabular}

Untuk kategori Cukup pada umumnya guru tidak mencantumkan Identitas dengan lengkap, pada indikator $\mathrm{A}$, pada indikator $\mathrm{C}$ materi pokok tidak dituliskan, serta pada Indikator G point 2 guru belum seluruhnya menggali dari peserta didik.

Tabel 3. Hasil Analisis RPP pada SD 23

Dari tabel di atas dapat dituliskan, Sekolah yang memperoleh kategori Cukup ada 6 sekolah yaitu sebanyak 75\% untuk kategori Baik 2 sekolah $25 \%$, secara keseluruhan Nilai rata-rata KD 43 dengan skor 78,18 kategori Cukup. untuk lebih jelasnya perolehan dari masing-masing sekolah ada pada tabel berikut

Tabel 2. Hasil Analisis RPP pada SD 08

\begin{tabular}{|l|c|c|c|c|l|}
\hline No & SD & $\begin{array}{c}\text { Guru } \\
\text { Kelas }\end{array}$ & $\begin{array}{c}\text { Jumlah } \\
\text { KD }\end{array}$ & $\begin{array}{c}\text { Skor } \\
\text { KD }\end{array}$ & $\begin{array}{c}\text { Kategor } \\
\text { i }\end{array}$ \\
\hline 1. & $\begin{array}{l}\text { SD } \\
08\end{array}$ & I & 44 & 80 & B \\
\hline 2. & & II & 45 & 81,82 & B \\
\hline 3. & & III & 41 & 74,55 & C \\
\hline 4. & & IV & 48 & 87,27 & B \\
\hline 5. & & V & 36 & 65,45 & K \\
\hline 6. & & VI & 44 & 80 & B \\
\hline & & PAI & 45 & 81,82 & B \\
\hline & & PJOK & 48 & 87,27 & B \\
\hline \multicolumn{2}{|r|}{ JUMLAH } & 351 & 638,18 & \\
\hline \multicolumn{2}{|r|}{ RATA-RATA } & 43,87 & 79,77 & C \\
\hline
\end{tabular}

Dari tabel diatas dapat dilihat bahwa penyusunan RPP di SD 08 pada umumnya sudah sesuai dengan yang di harapkan pada kurikulum 2013. Guru yang memperoleh nilai Kurang 1(satu) orang $12,5 \%$ orang, me.peroleh nilai Cukup 1 orang 12,5\% dan memperoleh nilai Baik ada 6 Orang 75\%. Guru kelas III memperoleh nilai kurang dari data yang diterima dalam pembuatan RPP guru dalam Indikator B ( Kompetensi Inti) tidak mencantumkan dalam RPP, pada Ondikator Tujuan Pembelajaran KI 1 dan 2 tidak dituliskaa, begitu juga untuk Indikator Kegiatan Pendahuluan guru tidak menuliskan mengaitkan pembelajaran pada pembelajaran yang terdahulu.

\begin{tabular}{|c|c|c|c|c|c|}
\hline No. & SD & $\begin{array}{l}\text { Guru } \\
\text { Kelas }\end{array}$ & $\begin{array}{c}\text { Jumlah } \\
\text { KD }\end{array}$ & $\begin{array}{l}\text { Skor } \\
\text { KD }\end{array}$ & Kategori \\
\hline 1. & $\begin{array}{l}\text { SD } \\
\mathrm{N} \\
23\end{array}$ & $\mathrm{I}$ & 37 & 67,27 & $\mathrm{~K}$ \\
\hline 2. & & II & 39 & 70,91 & $\mathrm{C}$ \\
\hline 3. & & III & 42 & 79,36 & $\mathrm{C}$ \\
\hline 4. & & IV & 41 & 74,55 & $\mathrm{C}$ \\
\hline 5. & & $\mathrm{~V}$ & 51 & 92,73 & $\mathrm{AB}$ \\
\hline 6. & & VI & 40 & 72,73 & $\mathrm{C}$ \\
\hline 7 & & PAI & 43 & 78,18 & $\mathrm{C}$ \\
\hline 8 & & PJOK & 47 & 83,45 & $\mathrm{~B}$ \\
\hline \multicolumn{3}{|c|}{ JUMLAH } & 340 & 619,18 & \\
\hline \multicolumn{3}{|c|}{ RATA-RATA } & 42,5 & 77,39 & $\mathrm{C}$ \\
\hline
\end{tabular}

Tabel diatas menunjukkan hasil analisis RPP pada SD 23. Guru yang memperoleh nilai Kurang 1(satu) orang $12,5 \%$ orang, me.peroleh nilai Cukup 5 orang 62,5\% dan memperoleh nilai Baik ada 1 Orang 12,5\%.Dan guru yang memperoleh nilai Amat Baik juga 1 (satu) orang $12,5 \%$. Guru kelas I memperoleh nilai kurang dari data yang diterima dalam pembuatan RPP guru dalam Indikator C ( Kompetensi Dasar) tidak mencantumkan dalam RPP, pada Indikator Tujuan Pembelajaran KI 1 dan 2 tidak dituliskaa, begitu juga untuk Indikator Kegiatan Pendahuluan guru tidak menuliskan mengaitkan pembelajaran pada pembelajaran yang terdahulu.

Untuk kategori Cukup pada umumnya guru tidak mencantumkan Identitas dengan lengkap, pada indikator B, pada indikator $\mathrm{C}$ materi pokok tidak dituliskan, serta pada Indikator G point 2 dan 3 guru belum seluruhnya menggali dari peserta didik dan tidak menuliskan rangkaian kegiatan yang akan dilakukan oleh peserta didik. 
448 Analisis supervisi kepala sekolah dalam penyusunan RPP dan pelaksanaan model saintific di sekolah dasar - Wisma Diandra, Sufyarma Marsidin, Ahmad Sabandi, Ahmad Zikri

Tabel 4. Hasil Analisi RPP Pada SD 37

\begin{tabular}{|l|l|c|c|c|l|}
\hline No. & SD & $\begin{array}{c}\text { Guru } \\
\text { Kelas }\end{array}$ & $\begin{array}{c}\text { Jumlah } \\
\text { KD }\end{array}$ & $\begin{array}{c}\text { Skor } \\
\text { KD }\end{array}$ & Kategori \\
\hline 1. & $\begin{array}{l}\text { SD } \\
\text { N } \\
37\end{array}$ & I & 38 & 69,09 & K \\
\hline 2. & & II & 47 & 85,45 & B \\
\hline 3. & & III & 47 & 85,45 & B \\
\hline 4. & & IV & 40 & 72,73 & C \\
\hline 5. & & V & 41 & 74,55 & C \\
\hline 6. & & VI & 46 & 83,64 & B \\
\hline & & PAI & 42 & 76,36 & C \\
\hline \multicolumn{7}{|r|}{ JUMLAH } & 348 & 632,72 & PJOK & 47 & 85,45 & B \\
\hline \multicolumn{2}{|r|}{ RATA-RATA } & 43,5 & 79,5 & C \\
\hline
\end{tabular}

Tabel diatas menunjukkan hasil analisis RPP pada SD 37 Memperoleh nilai 348 dengan rata-rata 43,5 jika di tuliskan dalam penskoran memperoleh nilai 79,5 dengan predikat Cukup.

Guru yang memperoleh nilai Kurang 1 (satu) orang $12,5 \%$ orang, me.peroleh nilai Cukup 3 orang 37,5\% dan memperoleh nilai Baik ada 4 Orang $50 \%$.. Guru kelas I memperoleh nilai kurang dari data yang diterima dalam pembuatan RPP guru dalam Indikator C ( Kompetensi Dasar) tidak mencantumkan dalam RPP, pada Indikator Tujuan Pembelajaran KI 1 dan 2 tidak dituliskaa, begitu juga untuk Indikator Kegiatan Pendahuluan guru tidak menuliskan mengaitkan pembelajaran pada pembelajaran yang terdahulu.

Untuk kategori Cukup pada umumnya guru tidak mencantumkan Identitas dengan lengkap, pada indikator B, pada indikator C materi pokok tidak dituliskan, serta pada Indikator G point 2 dan 3 guru belum seluruhnya menggali dari peserta didik dan tidak menuliskan rangkaian kegiatan yang akan dilakukan oleh peserta didik.

Tabel 5. Hasil Analisis RPP pada SD 62

\begin{tabular}{|l|l|c|c|c|l|}
\hline No. & SD & $\begin{array}{c}\text { Guru } \\
\text { Kelas }\end{array}$ & $\begin{array}{c}\text { Jumlah } \\
\text { KD }\end{array}$ & $\begin{array}{c}\text { Skor } \\
\text { KD }\end{array}$ & Kategori \\
\hline 1. & $\begin{array}{l}\text { SD } \\
\text { N } \\
62\end{array}$ & I & & & B \\
\hline 2. & & II & 44 & 80,00 & B \\
\hline 3. & & III & 43 & 78,18 & C \\
\hline 4. & & IV & 54 & 98,18 & AB \\
\hline 5. & & V & 42 & 76,36 & C \\
\hline 6. & & VI & 45 & 81,82 & B \\
\hline
\end{tabular}

\begin{tabular}{|l|c|c|c|l|}
\hline & PAI & 43 & 78,18 & $\mathrm{C}$ \\
\hline & PJOK & 50 & 90,91 & $\mathrm{~B}$ \\
\hline \multicolumn{2}{|c|}{ JUMLAH } & 366 & 665,45 & \\
\hline \multicolumn{2}{|c|}{ Rata-Rata } & 45,75 & 83,18 & $\mathrm{~B}$ \\
\hline
\end{tabular}

Tabel diatas menunjukkan hasil analisis RPP pada SD 62 Memperoleh nilai 366 dengan rata-rata 45,75 jika di tuliskan dalam penskoran memperoleh nilai 83,18 dengan predikat Baik

. Guru yang memperoleh nilai Cukup 3 orang 37,5\% dan memperoleh nilai Baik ada 4 Orang $50 \%$. Memperoleh nilai Amat Baik 1 (satu) orang 12,5\%, Guru kelas V memperoleh nilai kurang dari data yang diterima dalam pembuatan RPP guru dalam Indikator A ( Identitas ) tidak mencantumkan dalam RPP, pada Indikator Tujuan Pembelajaran KI 1 dan 2 tidak dituliskaa, begitu juga untuk Indikator Kegiatan Pendahuluan guru tidak menuliskan mengaitkan pembelajaran pada pembelajaran yang terdahulu.

Tabel 6. Hasil Analisis RPP pada SD 64

\begin{tabular}{|c|c|c|c|c|c|}
\hline No. & SD & $\begin{array}{l}\text { Guru } \\
\text { Kelas }\end{array}$ & $\begin{array}{c}\text { Jumlah } \\
\text { KD }\end{array}$ & $\begin{array}{l}\text { Skor } \\
\text { KD }\end{array}$ & Kategori \\
\hline 1. & \begin{tabular}{|l|}
$\mathrm{SD}$ \\
$\mathrm{N}$ \\
64 \\
\end{tabular} & I & 42 & 76,36 & $\mathrm{C}$ \\
\hline 2. & & II & 49 & 89,09 & B \\
\hline 3. & & III & 43 & 78,18 & $\mathrm{C}$ \\
\hline 4. & & IV & 47 & 85,45 & B \\
\hline 5. & & V & 47 & 85,45 & B \\
\hline 6. & & VI & 46 & 83,64 & B \\
\hline & & PAI & 46 & 83,64 & B \\
\hline & & PJOK & 50 & 90,91 & $\mathrm{AB}$ \\
\hline \multicolumn{3}{|c|}{ JUMLAH } & 370 & 672,22 & \\
\hline \multicolumn{3}{|c|}{ Rata-Rata } & 46,25 & 84,09 & B \\
\hline
\end{tabular}

Tabel diatas menunjukkan hasil analisis RPP pada SD 64 Memperoleh nilai 370 dengan rata-rata 46,25 jika di tuliskan dalam penskoran memperoleh nilai 84,09 dengan predikat Baik.

Guru yang memperoleh nilai Cukup 2 orang $25 \%$ dan memperoleh nilai Baik ada 5 Orang 62,5 \%. Sementera untyk nilai Amat Baik ada 1 orang 12,5\%. Untuk kategori Cukup pada umumnya guru tidak mencantumkan Identitas dengan lengkap, pada indikator B, pada indikator C materi pokok tidak dituliskan, serta pada Indikator $\mathrm{G}$ point 2 dan 3 guru belum seluruhnya 
menggali dari peserta didik dan tidak menuliskan rangkaian kegiatan yang akan dilakukan oleh peserta didik.

Tabel 7. Hasil Analisis RPP pada MIS

\begin{tabular}{|l|c|c|c|c|l|}
\hline No. & SD & $\begin{array}{c}\text { Guru } \\
\text { Kelas }\end{array}$ & $\begin{array}{c}\text { Jumlah } \\
\text { KD }\end{array}$ & $\begin{array}{c}\text { Skor } \\
\text { KD }\end{array}$ & Kategori \\
\hline 1. & MIS & I & 41 & 74,55 & C \\
\hline 2. & & II & 46 & 83,64 & B \\
\hline 3. & & III & 41 & 74,55 & C \\
\hline 4. & & IV & 45 & 81,82 & B \\
\hline 5. & & V & 47 & 85,45 & B \\
\hline 6. & & VI & 46 & 83,64 & B \\
\hline & & PAI & 47 & 85,45 & B \\
\hline \multicolumn{7}{|r|}{ JUMLAH } & PJOK & 51 & 92,73 & AB \\
\hline \multicolumn{7}{|r|}{ Rata-Rata } & 364 & 661,81 & \\
\hline \multicolumn{7}{|l}{} \\
\hline
\end{tabular}

Tabel diatas menunjukkan hasil analisis RPP pada SD MIS Memperoleh nilai 364 dengan rata-rata 45,5 jika di tuliskan dalam penskoran memperoleh nilai 82,72 dengan predikat Cukup.

. Guru yang memperoleh nilai Cukup 5 orang $62.5 \%$ dan memperoleh nilai Baik ada 3 Orang $37,5 \%$. Untuk kategori Cukup pada umumnya guru tidak mencantumkan Identitas dengan lengkap, pada indikator $\mathrm{C}$, pada indikator D materi pokok tidak dituliskan, serta pada Indikator $\mathrm{G}$ point 5 dan 6 guru belum seluruhnya menggali dari peserta didik dan tidak menuliskan rangkaian kegiatan yang akan dilakukan oleh peserta didik.

Tabel 23. Hasil Analisis RPP pada MIN

\begin{tabular}{|l|c|c|c|c|l|}
\hline No. & $\begin{array}{c}\text { SD } \\
\text { MIN }\end{array}$ & $\begin{array}{c}\text { Guru } \\
\text { Kelas }\end{array}$ & $\begin{array}{c}\text { Jumlah } \\
\text { KD }\end{array}$ & $\begin{array}{c}\text { Skor } \\
\text { KD }\end{array}$ & Kategori \\
\hline 1. & & I & 42 & 76,36 & C \\
\hline 2. & & II & 45 & 81,82 & B \\
\hline 3. & & III & 52 & 94,55 & AB \\
\hline 4. & & IV & 47 & 85,45 & B \\
\hline 5. & & V & 45 & 81,82 & C \\
\hline 6. & & VI & 48 & 87,27 & B \\
\hline & & PAI & 50 & 90,91 & B \\
\hline \multicolumn{7}{|r|}{ JUMLAH } & PJOK & 50 & 90,91 & B \\
\hline \multicolumn{7}{|c|}{ Rata-Rata } & 47,37 & 689.09 & 86,13 & B \\
\hline
\end{tabular}

Tabel diatas menunjukkan hasil analisis RPP pada SD MIN Memperoleh nilai 379 dengan rata-rata 47,37 jika di tuliskan dalam penskoran memperoleh nilai 86,13 dengan predikat Baik.

Guru yang memperoleh nilai Cukup 2 orang $25 \%$ dan memperoleh nilai Baik ada 5 Orang 62,5\%. Untuk nilai Amat Baik 1 orang $12,5 \%$. Untuk kategori Cukup pada umumnya guru terlupa mencantumkan Identitas dengan lengkap, pada indikator A, pada indikator $\mathrm{C}$ materi pokok tidak dituliskan, serta pada Indikator G point 3 dan 5 guru belum seluruhnya menggali dari peserta didik dan tidak menuliskan rangkaian kegiatan yang akan dilakukan oleh peserta didik.

Tabel 8 Rekap Analisis sebelum supervi dan setelah supervisi

\begin{tabular}{|c|c|c|c|c|}
\hline NO & SD N & $\begin{array}{c}\text { Skor } \\
\text { sebelum } \\
\text { supervisi }\end{array}$ & $\begin{array}{c}\text { Skor setelah } \\
\text { supervisi }\end{array}$ & Selisih \\
\hline 1 & 08 & 79,77 & 85,68 & 5,91 \\
\hline 2 & 23 & 77,39 & 80,45 & 3,06 \\
\hline 3 & 37 & 79,5 & 81,36 & 1,95 \\
\hline 4 & 50 & 69,09 & 83,63 & 14,09 \\
\hline 5 & 62 & 80,60 & 83,18 & 2,58 \\
\hline 6 & 64 & 79,54 & 84,09 & 4,55 \\
\hline 7 & MIS & 78,63 & 82,72 & 4,09 \\
\hline 8 & MIN & 84,32 & 86,13 & 1.81 \\
\hline JUMLAH & 5003,53 & 689.09 & 36,32 \\
\hline \multicolumn{2}{|c|}{ Rata-rata } & 78,18 & 86,13 & 4,52 \\
\hline
\end{tabular}

Dari semua uraian tabel diatas, dapat disimpulkan bahwa guru kelas SD Negeri 08 sebelum supervisi memperoleh nilai 79,77 kategori Cukup(C) setelah tindak lanjut memperoleh skor 85,68 Kategori Baik, selisih skor adalah 5,91\% . guru kelas SD Negeri 23 sebelum supervisi memperoleh nilai 77,39 kategori $\operatorname{Cukup}(\mathrm{C})$ setelah tindak lanjut memperoleh skor 80,45 Kategori Baik, selisih skor adalah 3,06\%. guru kelas SD Negeri 37 sebelum supervisi memperoleh nilai 79,5 kategori Cukup(C) setelah tindak lanjut memperoleh skor 81, 36Kategori Baik, selisih skor adalah 5,91\%.

Sementara guru kelas SD Negeri 50 sebelum supervisi memperoleh nilai 79,77 kategori Cukup $(C)$ setelah tindak lanjut memperoleh skor 85,68 Kategori Baik, selisih skor adalah 5,91\%. 
450 Analisis supervisi kepala sekolah dalam penyusunan RPP dan pelaksanaan model saintific di sekolah dasar - Wisma Diandra, Sufyarma Marsidin, Ahmad Sabandi, Ahmad Zikri

Guru kelas SD Negeri 62 sebelum supervisi memperoleh nilai 80,60 kategori Baik (B) setelah tindak lanjut memperoleh skor 83,18 Kategori Baik, selisih skor adalah 2,58\%. Guru kelas SD Negeri 64 sebelum supervisi memperoleh nilai 79,54 kategori Cukup(C) setelah tindak lanjut memperoleh skor 84,09 Kategori Baik, selisih skor adalah $4.55 \%$.

Dari data diatas maka pada Kecamatan Latina Kota Payakumbuh sudah menyusun RPP dengan kategori "Baik". Guru-guru telah dapat menulis RPP dengan baik memenuhi semua indikator yang ada pada lembaran telaah RPP.

Bagaimana guru-guru SD Negeri di Kecamatan Latina dalam menyusun RPP kurikulum 2013. . Rencana Pelaksanaan Pembelajaran (RPP) adalah salah satu komponen yang harus dipersiapkan guru dalam menjalankan kegiatan pembelajaran dalam Kurikulum 2013 SD atau Kurikulum 2013 Revisi. RPP merupakan perencanaan yang dilakukan oleh guru sebelum mulai mengajar di ruang kelas.

Dengan membuat RPP, guru menjadi lebih siap dan tahu tujuan pembelajaran berdasarkan tema yang sedang dipelajari. Pelaksanaan pembelajaran pun menjadi lebih efektif dan berkualitas berdasarkan panduan RPP. Guru juga dapat dengan mudah melakukan penilaian atas hasil belajar siswa berdasarkan format yang telah dibuat sebelumnya. Penyusunan RPP merupakan salah satu faktor yang dapat meningkatkan kualitas belajar.

Sebagian guru SD di Kecamatan Latina merasa kesulitan untuk menyusun RPP Kurikulum 2013 SD. Namun, dengan panduan yang tepat, hal ini dapat diatasi. Berikut adalah beberapa hal yang menjadi panduan mereka dalam menyusun RPP.

Supervisi kepala sekolah terhadap RPP yang dibuat guru-guru SD Negeri di Kecamatan Latina. Salah satu tugas kepala sekolah di
Kecamatan Latina adalah melaksanakan supervisi akademik. Untuk melaksanakan supervisi akademik secara efektif diperlukan keterampilan konseptual, interpersonal dan teknikal (Glickman, at al. 2007). Oleh sebab itu, setiap kepala sekolah harus memiliki dan menguasai konsep supervisi akademik yang meliputi: pengertian, tujuan dan fungsi, prinsip-prinsip, dan dimensi-dimensi substansi supervisi akademik.

Supervisi akademik yang dilakukan kepala sekolah di Kecamatan Latina antara lain adalah sebagai berikut; (1) Memahami konsep, prinsip, teori dasar, karakteristik, dan kecenderungan perkembangan tiap bidang pengembangan pembelajaran kreatif, inovatif, pemecahan masalah, berpikir kritis dan naluri kewirausahaan.

(2) Membimbing guru dalam menyusun silabus tiap bidang pengembangan di sekolah atau mata pelajaran di sekolah berlandaskan standar isi, standar kompetensi dan kompetensi dasar, dan prinsip-prinsip pengembangan KTSP. (3) Membimbing guru dalam memilih dan menggunakan strategi/ metode/teknik pembelajaran/bimbingan yang dapat mengembangkan berbagai potensi siswa. (4) Membimbing guru dalam melaksanakan kegiatan pembelajaran/bimbingan (di kelas, laboratorium, dan/atau di lapangan) untuk mengembangkan potensi siswa. (5) Membimbing guru dalam mengelola, merawat, mengembangkan dan menggunakan media pendidikan dan fasilitas pembelajaran. (6) Memotivasi guru untuk memanfaatkan teknologi informasi untuk pembelajaran.

Kompetensi supervisi akademik intinya adalah membina guru dalam meningkatkan mutu proses pembelajaran. Sasaran supervisi akademik adalah guru dalam melaksanakan proses pembelajaran, yang terdiri dari materi pokok dalam proses pembelajaran, penyusunan silabus dan RPP, pemilihan strategi/metode/teknik 
451 Analisis supervisi kepala sekolah dalam penyusunan RPP dan pelaksanaan model saintific di sekolah dasar - Wisma Diandra, Sufyarma Marsidin, Ahmad Sabandi, Ahmad Zikri

pembelajaran, penggunaan media dan teknologi informasi dalam pembelajaran, menilai proses dan hasil pembelajaran serta penelitian tindakan kelas. Oleh karena itu, materi ini diharapkan dapat memberikan wawasan kepada Kepala Sekolah dalam meningkatkan kompetensi supervisi akademik yang meliputi: (1) memahami konsep supervisi akademik, (2) membuat rencana program supervisi akademik, (3) menerapkan teknik-teknik supervisi akademik, (4) menerapkan supervisi klinis, dan (5) melaksanakan tindak lanjut supervisi akademik.

\section{SIMPULAN}

Berdasarkan uraian yang telah penulis sajikan pada halaman-halaman terdahulu, dapatlah diambil kesimpulan sebagaiberikut: Pemahaman guru SD di Kecamatan Latina tentang RPP cukup bervariasi, pada intinya mereka cukup baik dalam memahami tentang media, walaupun ada diantara mereka RPP dalam artian yang terlalu umum. Langkah-langkah yang dilakukan oleh guru SD di Kecamatan Latina dalam menyusun RPP adalah: a menyiapkan alat tulis, b. Melihat dan mempelajari Buku Paket Mata Pelajaran, c. Menuliskan Rencana Pelaksanaan Pembelajaran ke dalam buku. Faktor penghambat bagi guru SD di Kecamatan Latina dalam menyusun RPP adalah: a.keterbatasan finansial, b. Kurang menguasai teori penyusunan RPP yang sempurna, c. keterbatasan media pendukung.

\section{DAFTAR PUSTAKA}

Asmendri, A., Marsidin, S., Rusdinal, R., \& Mukhaiyar, M. (2018). An Analysis Of Managerial Competence Of The Madrasah Principals In Islamic Senior High School In Tanah Datar. Al-Ta Lim Journal. Https://Doi.Org/10.15548/Jt.V25i1.350

Baridan, M. A. (2016). Implementasi Pembelajaran Tematik Terpadu Sekolah Dasar Negeri Se Kecamatan Sungai Raya Kabupaten Kuburaya. Jurnal Pendidikan Dan Pembelajaran, 2(1), 1-12.
Creswell, J. W. (2016). Research Design: Pendekatan Metode Kualitatif, Kuantitatif, Dan Campuran. SAGE Publication.

Dahliana. (2014). Peningkatan Aktivitas Peserta Didik Dalam Pembelajaran Tematik Terpadu Menggunakan Pendekatan Saintifik Di Kelas I. Jurnal Pendidikan Dan Pembelajaran, 2(1), 203.

Depdiknas. (2003). Undang-Undang RI No 20 Tahun 2003. Undang-Undang Republik Indonesia Nomor 20 Tahun 2003 Tentang Sistem Pendidikan Nasional Dengan Rahmat Tuhan Yang Maha Esa Presiden Republik Indonesia.

Depdiknas. (2006). Panduan Penyusunan Kurikulum Tingkat Satuan Pendidikan. Jakarta: BNSP Depdiknas.

E. Mulyasa. (2013). Uji Kompetensi Dan Penilaian Kinerja Guru. In Uji Kompetensi Dan Penilaian Kinerja Guru.

Kusno. (2014). Peningkatan Aktivitas Peserta Didik Dalam Pembelajaran Tematik Terpadu Menggunakan Pendekatan Saintifik Di Kelas IV. Jurnal Pendidikan Dan Pembelajaran, 2(1), 203.

Mislinawati., M., \& Nurmasyitah., N. (2018). KENDALA GURU DALAM MENERAPKAN MODEL-MODEL PEMBELAJARAN BERDASARKAN KURIKULUM 2013 PADA SD NEGERI 62 BANDA ACEH. Jurnal Pesona Dasar. Https://Doi.Org/10.24815/Pear.V6i2.12194

Muslich, M. (2008). KTSP Pembelajaran Berbasis Kompetensi Dan Kontekstual. Jakarta: PT. Bumi Aksara. Https://Doi.Org/10.1016/J.Sbspro.2014.09.35 2

Piaget, J. (2010). Pektumbuhan Dan Perkembangan.

Https://Doi.Org/10.2139/Ssrn.1632203

Salihin. (2014). Peningkatan Minat Peserta Didik Dalam Pembelajaran Tematik Terpadu Menggunakan Pendekatan Saintifik Di SD. Jurnal Pendidikan Dan Pembelajaran, 2(1), 561-565.

Sufairoh. (2016). Pendekatan Saintifik Dan Model Pembelajaran K-13. Bahastra. Https://Doi.Org/10.26555/Bahastra.V37i1.56 41

Tarmili. (2016). Penerapan Pendekatan Saintifik Dalam Pembelajaran Tematik Terpadu Di 
452 Analisis supervisi kepala sekolah dalam penyusunan RPP dan pelaksanaan model saintific di sekolah dasar - Wisma Diandra, Sufyarma Marsidin, Ahmad Sabandi, Ahmad Zikri

Kelas Iv Sekolah Dasar Kota Singkawang.

Jurnal Pendidikan Dan Pembelajaran, 3(1), 31-48.

Utami, B., Yamtinah, S., \& ES, W. A. (2016). Analisis Rencana Pelaksanaan Pembelajaran Tematik Yang Disusun Guru SD. In Peningkatan Kualitas Pembelajaran Sains Dan Kompetensi Guru Melalui Penelitian \& Pengembangan Dalam Menghadapi Tantangan Abad-21. 